\title{
A multi-elemental study to establish the natural background and geochemical anomalies in rocks from the Sonora river upper basin, NW Mexico
}

\section{Thierry Calmus', Martín Valencia-Moreno1, Rafael Del Río-Salas ${ }^{1, *}$, Lucas Ochoa-Landín ${ }^{2}$, and Héctor Mendivil-Quijada ${ }^{3}$}

${ }^{1}$ Estación Regional del Noroeste, Instituto de Geología, Universidad Nacional Autónoma de Mexico, L.D. Colosio y Madrid S/N, Col. Los Arcos, Hermosillo, Sonora, 83240, Mexico.

${ }^{2}$ Departamento de Geología, Universidad de Sonora, Blvd. Luis Encinas y Rosales S/N, Col. Centro, Hermosillo, Sonora, 83000, Mexico.

${ }^{3}$ GEO Digital Imaging de México, S.A. de C.V., Avenida Dr. Paliza 94, Col. Centenario,

Hermosillo, Sonora, 83260, Mexico.

*rdelriosalas@gmail.com

\begin{abstract}
Growing industrialization, including mining activity, dramatically increases environmental pollution. Exploitation of natural resources triggers landscape alteration, inputs of potentially toxic chemical elements to the environment and health diseases. In the case of mining activity, the measure of any associated environmental disturbance requires a geochemical background as a reference frame. Since in Mexico, there is a lack of this type of references in mining districts, the present study took a recent mining spill as an opportunity to establish the geochemical background of the upper Sonora river basin, which includes active and historical mining areas. The weighted average of elemental values was calculated using GIS tools. The data show that rocks have a similar geochemical behavior, which is characterized by pristine enrichment of $\mathrm{Mn}, \mathrm{Ca}, \mathrm{P}, \mathrm{Ba}, \mathrm{Zn}, \mathrm{As}, \mathrm{Ag}, \mathrm{Sb}, \mathrm{W}, \mathrm{Pb}$ and $\mathrm{Bi}$ relative to the upper continental crust. Coefficients of variation values reveal that $\mathrm{Sc}, \mathrm{Y}, \mathrm{Zr}, \mathrm{Ce}, \mathrm{Yb}, \mathrm{Fe}, \mathrm{Ti}$ and $\mathrm{Al}$ display a conservative behavior and, therefore, they are recommended to be used as reference elements in environmental studies in the basin. The findings of this work highlight the need of determining the geochemical background in mining regions to reach more realistic environmental assessments.
\end{abstract}

Key words: geochemical background; conservative reference elements; Sonora river upper basin; mining district, Mexico.

\section{RESUMEN}

La creciente industrialización, incluyendo la actividad minera, incrementa dramáticamente la contaminación ambiental. La explotación de los recursos naturales altera el paisaje, incorpora elementos químicos potencialmente tóxicos al medio ambiente y desencadena enfermedades.
En el caso de la actividad minera, la determinación de cualquier perturbación ambiental requiere de un fondo geoquímico de las rocas como marco de referencia. El presente estudio tomó un derrame minero reciente como una oportunidad para establecer el fondo geoquímico de la cuenca alta del río Sonora, la cual incluye áreas mineras activas e históricas. Los datos muestran que las rocas tienen un comportamiento geoquímico similar entre ellas, caracterizado por anomalías positivas de $\mathrm{Mn}, \mathrm{Ca}$, $P, B a, Z n, A s, A g, S b, W, P b$ y Bi en relación con la corteza continental superior. Los valores de coeficiente de variación revelan que $S c, Y, Z r$, $\mathrm{Ce}, \mathrm{Yb}, \mathrm{Fe}$, Ti y Al muestran un comportamiento conservador y, por lo tanto, se recomiendan para ser utilizados en estudios ambientales en la cuenca. Los hallazgos de este trabajo resaltan la necesidad de determinar el fondo geoquímico en las regiones mineras para realizar evaluaciones ambientales más realistas.

Palabras clave: fondo geoquímico; elementos conservadores de referencia; cuenca alta del río Sonora; distrito minero, México.

\section{INTRODUCTION}

The assessment of pollution impact due to anthropogenic activities usually requires geochemical reference values (e.g. Pan et al., 2017a; Akopyan et al., 2018). Among these activities, mining is known as a source of pollution, which may include mining residues, spills and dam failures, dust emissions (Nordstrom, 2015). This highlights the need of establishing reference values in mining districts to properly evaluate possible environmental disturbances (e.g. Martínez et al., 2007), in soils, sediments, surficial waters, aquifers, dust, etc.

In environmental studies, the reference values that constitute the geochemical baseline are commonly the result of a combination between anthropogenic and geogenic contributions in surficial 
environments (Salminen and Gregorauskiene, 2000; Reimann and Garrett, 2005). Likewise, the term natural background has been coined to represent the geogenic end-member, which reflects the geochemical composition due to natural processes uninfluenced by human activities (Reimann and Garrett, 2005). In the case of mining districts, the geochemical background takes into account the possible high values from mineralized zones (Hawkes and Webb, 1962); thus, these values do not represent anthropogenic inputs. For instance, a $\mathrm{Cu}$-mineralized zone will naturally provide high values of copper to the geochemical background. In other words, rocks constitute the unique source to define a geochemical background unperturbed by human activities.

On August 6 of 2014 a spill of $40000 \mathrm{~m}^{3}$ of Fe-Cu acid solution occurred at the top of Tinajas creek, due to a failure of the Tinajas dam (Figure 1), at the Buenavista del Cobre mine (formerly Cananea mine) in Sonora, northwestern Mexico. Because of the Tinajas creek drains downstream into the upper part of the Sonora river hydrologic system and contributes to aquifer recharge, this incident triggered a major socio-economic and political concern, mainly because this system provides surficial water for agricultural and livestock activities. Moreover, the Sonora river supplies water to the El Molinito dam (Figure 1), which in turn provides water to Hermosillo (Figure 1), the capital city of Sonora state. The environmental Mexican authorities (Secretaría de Medio Ambiente y Recursos Naturales, SEMARNAT) together with Grupo Mexico, the owner of the Buenavista del Cobre mine, signed an agreement to evaluate the possible environmental, social and economical impact related to the spill.

One of the issues in the agreement was the establishment of a natural geochemical background, which is absolutely necessary to quantify the possible impact of the spill to ecosystems. Even though Mexico has developed important mining activities since the $16^{\text {th }}$ century, as far as we know, there is no published information regarding the natural background from rocks. However, there are some works regarding the geochemical composition of soils and sediments determined at regional scale in mining districts of Mexico, which include both natural background and baseline levels (Chiprés et al., 2008; 2009; Gutiérrez et al., 2012; Miranda-Avilés et al., 2012). The main reason for that is because it is quite difficult to discern from pristine soils and sediments from
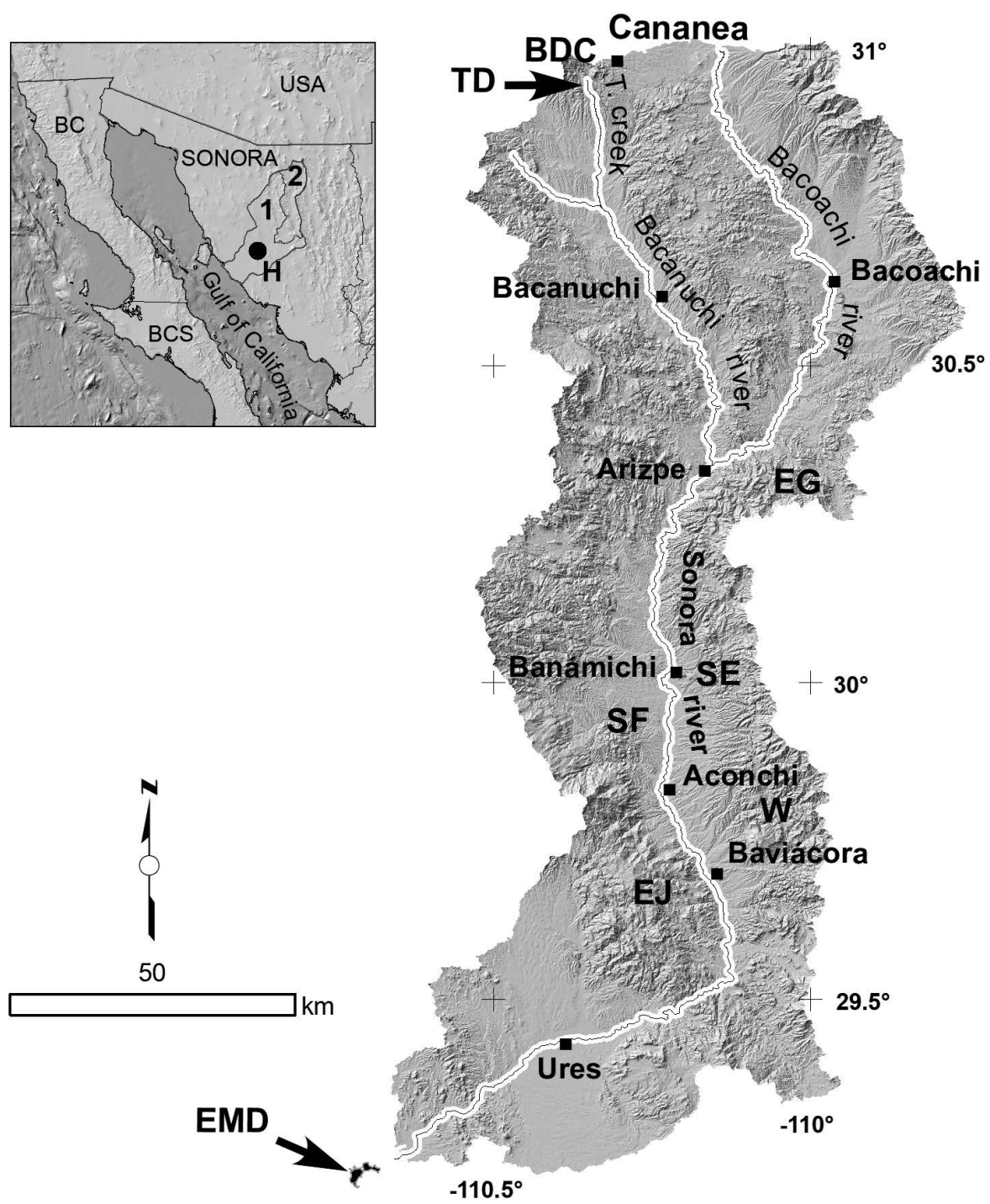

Figure 1. Map showing the Sonora river upper basin with the main hydrologic net. 1: Sonora river basin; 2: Sonora river upper basin; BC: Baja California State; BCS: Baja California Sur State; BDC: Buenavista del Cobre; EG: El Gachi; EJ: El Jaralito; EMD: El Molinito dam; H: Hermosillo; SE: Santa Elena; SF: San Felipe; TD: Tinajas dam; W: Washington. 
those that were impacted by human activity (Chiprés et al., 2009). This is particularly critical for the study area, since large scale to artisanal mining activity, also including mining wastes from historical mining operations is widespread along the Sonora river basin. Moreover, soils and sediments must be highly affected by agricultural and cattle industry, which is a primary economic activity in the region. Thus, the aim of this research is to establish the natural geochemical background from rocks exposed along the basin. This natural background will allow discriminating between the original geochemical signatures from that modified by anthropogenic contributions, in favor of more properly assess environmental impacts in the region.

\section{GEOLOGICAL FRAMEWORK}

The Sonora river upper basin is located at the southwestern margin of the North American craton. In this area, the Proterozoic basement is composed by crystalline rocks of the Mazatzal and Yavapay provinces, which accreted to each other at $1.63 \mathrm{Ga}$ (Iriondo and Premo, 2011). The Mazatzal province is characterized by the 1.69 to $1.64 \mathrm{Ga}$ old Pinal schist (Anderson and Silver, 2005; Page et al., 2010), which were intruded by Mesoproterozoic plutons, such as the 1.44 Ga Cananea granite (Anderson and Silver, 1977; Noguez-Alcántara, 2008). The Yavapay province is characterized by metamorphic rocks intruded by the $1.73 \mathrm{Ga}$ Creston granite (Valenzuela-Navarro et al., 2005. Neoproterozoic and Paleozoic rocks are poorly represented in the Sonora river upper basin. However, some outcrops are present in the Bacoachi area and west of Cananea town (Figure 1), as well as roof-pendants in the Laramide El Jaralito batholith (Roldán-Quintana, 1991), west of Baviácora (Figure 1).

Since the Late Permian until Late Miocene, the tectonic evolution was mainly controlled by the subduction of oceanic plates of the Pacific realm below the North American plate. In the study area, Jurassic rocks recorded the magmatic arc activity, as well as back-arc basins development along the continental margin (Dickinson and Lawton, 2001; Mauel et al., 2011). During Early Cretaceous, shallow marine sedimentary rocks of the Bisbee Group were deposited during the marine transgression from the Gulf of Mexico. During Late Cretaceous and Paleocene occurred an intense igneous activity along the North American Cordillera, known in Sonora as the 80-40 Ma Laramide magmatic event (Coney and Reynolds, 1977). This event is well represented in the study area, which is highlighted by the Aconchi batholith (Figure 1), and widespread volcanic rocks of the Tarahumara and Mesa Formations.

The igneous activity continued during Cenozoic time, locally represented by 25 and 23 Ma old rhyolitic and dacitic domes (GonzálezLeón et al., 2010), which correspond to the westernmost manifestations of the Sierra Madre Occidental volcanic province. During the Late Oligocene-Miocene, the Basin and Range extensional tectonic event strongly thinned the crust, resulting in a series of NS to NNW-SSW elongated horsts and grabens, limited by deep-seated normal faults. The extension was characterized by tectonic exhumation controlled by low-angle normal fault activity, characterized by high erosion rate and great volumes of clastic sediments of the Báucarit Formation and the Sonora Group (Grijalva-Noriega and Roldán-Quintana, 1998), which filled the grabens. Contemporaneously with that crustal thinning, basaltic flows were outpoured (González-León et al., 2010), for example in the Arizpe area (Figure 1).

\section{Mining districts}

Along the Sonora river upper basin there are several zones characterized by hydrothermal alteration or mineralization, which form part of the geochemical background. Hence, some of them include currently active mines while many others deposits are unexploited or underwent production. Figure 1 shows, from north to south, the main mining developments, which correspond to the $\mathrm{Cu}-\mathrm{Mo}$ Buenavista del Cobre, the Pb-Zn El Gachi, the Ag (Au) Santa Elena, the Pb-Zn ( $\mathrm{Au}$ ) San Felipe, the tungsten El Jaralito and the $\mathrm{Cu}-\mathrm{W}-\mathrm{Mo}$ Washington mining sites.

\section{MATERIAL AND METHODS}

\section{Study area}

The study area corresponds to the Sonora river upper basin, which is located between the Cananea town to the north, and the El Molinito dam to the south (Figure 1), with a total surface of 9292 $\mathrm{km}^{2}$. This region has several mining developments, most of them with intermittent activity, and some of them under production, including the Buenavista del Cobre porphyry copper mine, which is the largest mine in Mexico, and one of the largest copper deposit at world-scale (Titley, 1993).

\section{Lithological categorization}

The geochemical background depends on several factors, among which the geology and lithology are key factors (Hao et al., 2014). The geology differs from lithology because it takes in account the spatial-temporal relationships and genesis of rocks, as well as structural features. The concentration of elements is influenced by many factors; however, assuming that landscape characteristics remain relatively unchanged, the surficial lithology is a key factor influencing the geochemical background. Therefore, the background values of metallic elements considerably vary from one area to another, depending on the petrographic and geochemical composition of outcropping rocks. In order to establish the representative rock types and to select sampling sites, a geological basemap was synthetized from 1:50,000 and 1:250000 geological maps published by the Mexican Geological Survey (Servicio Geológico Mexicano, SGM). The lithology was categorized into 11 units, according to their nature and regardless the age of formation (Table 1; Figure 2). For instance, considering their similar compositions, Cretaceous and Cenozoic felsic volcanic rocks were categorized into a single unit named "felsic volcanic rocks".

\section{Sampling and Geographic Information System}

The Sonora river upper basin was divided into three sectors, which correspond to the three main sub-basins (inset of Figure 2): (i) Sector A $\left(1479 \mathrm{~km}^{2}\right)$ corresponds to the watershed drained by the Tinajas creek, which received the spill in first instance, and the Bacanuchi river; (ii) Sector B $\left(2278 \mathrm{~km}^{2}\right)$ corresponds to the Bacoachi river sub-basin, and (iii) Sector C, which is the largest and southernmost sub-basin $\left(5535 \mathrm{~km}^{2}\right)$, and receives discharges from sectors A and B. Considering the lithological categorization, a total of 73 rock samples were selected to perform the geochemical studies (Figure 2).

Furthermore, sampling was constrained considering the area of exposure of each lithological unit, which was calculated for sectors A, B and C (Table 2), and recorded as an attribute to the sample. A geographic information system (GIS) was created using ArcGIS 10.3, in the UTM projection for the zone 12N, with WGS84 datum.

\section{Preparation and analytical techniques}

Rock samples were hammered in the collecting site to about a fist size, in order to avoid further contamination. The collected samples were crushed to fragments of about one $\mathrm{cm}$ in diameter, using a steel jaw-crusher at the Estación Regional del Noroeste, Universidad 
Table 1. List of the 11 units considered for the lithologic categorization (n: number of samples) and respective area (km2) of each unit for the three sectors A, B and C.

\begin{tabular}{|c|c|c|c|c|c|}
\hline \multirow[t]{2}{*}{ Units } & \multirow[t]{2}{*}{ Description } & \multicolumn{3}{|c|}{ Sector } & \multirow[t]{2}{*}{ References } \\
\hline & & $\mathbf{A}$ & B & $\mathbf{C}$ & \\
\hline $\begin{array}{l}\text { Unit } 1 \text { : } \\
\text { Non-consolidated detritic deposits } \\
(\mathrm{n}=4)\end{array}$ & $\begin{array}{l}\text { Plio-Quaternary unconsolidated clastic sediments, including } \\
\text { alluvium, alluvial fan and colluvium deposits excepting stream } \\
\text { sediments and soils. }\end{array}$ & 131 & 181 & 780 & \\
\hline $\begin{array}{l}\text { Unit 2: } \\
\text { Consolidated detritic deposits } \\
(\mathrm{n}=13)\end{array}$ & $\begin{array}{l}\text { Late Oligocene and Miocene conglomerate and sandstone of the } \\
\text { Báucarit Formation; Pliocene detritic sediments informally referred } \\
\text { to as Sonora Group. }\end{array}$ & 596 & 857 & 1507 & $\begin{array}{l}\text { King (1939); Grijalva-Noriega } \\
\text { and Roldán-Quintana (1998) }\end{array}$ \\
\hline $\begin{array}{l}\text { Unit } 4 \text { : } \\
\text { Marine sedimentary rocks }(\mathrm{n}=5)\end{array}$ & $\begin{array}{l}\text { Early Cretaceous marine sedimentary rocks belonging to the Bisbee } \\
\text { Group. }\end{array}$ & 15 & 44 & 164 & González-León et al. (2000) \\
\hline $\begin{array}{l}\text { Unit 5: } \\
\text { Volcanic felsic rocks }(n=10)\end{array}$ & $\begin{array}{l}\text { Late Cretaceous-Paleocene and Oligocene felsic volcanic rocks, } \\
\text { which belong to the Laramide magmatic arc and Sierra Madre } \\
\text { Occidental volcanic province, respectively. }\end{array}$ & 105 & 270 & 845 & $\begin{array}{l}\text { McDowell and Clabaugh (1979); } \\
\text { González-León } \text { et al. (2011) }\end{array}$ \\
\hline $\begin{array}{l}\text { Unit } 8 \text { : } \\
\text { Altered rocks }(n=20)\end{array}$ & $\begin{array}{l}\text { Altered volcanic and plutonic Jurassic or Laramide rocks. These } \\
\text { rocks are distinguished from Units } 5 \text { and } 7 \text {, since they were altered } \\
\text { by hydrothermal fluids and locally mineralized. Therefore their } \\
\text { original composition has been modified. }\end{array}$ & 129 & 78 & 234 & \\
\hline $\begin{array}{l}\text { Unit 9: } \\
\text { Quartzite }\end{array}$ & Paleozoic quartzite belonging to the Bolsa Quartzite. & & 1 & 5 & Stewart and Poole (2002) \\
\hline $\begin{array}{l}\text { Unit 10: } \\
\text { Metamorphic rocks }\end{array}$ & $\begin{array}{l}\text { Precambrian metamorphic rocks, which include gneisses and } \\
\text { schists. }\end{array}$ & & 32 & 2 & \\
\hline $\begin{array}{l}\text { Unit 11: } \\
\text { Contact metamorphic rocks }(n=3)\end{array}$ & $\begin{array}{l}\text { Limestone and sandstone affected by contact metamorphism, which } \\
\text { locally developed skarn zones. }\end{array}$ & & & 16 & \\
\hline
\end{tabular}

Nacional Autónoma de México (UNAM). A fraction of the crushed samples was sent to ActLabs laboratories in Canada, where they were powdered using an agate mill. The concentrations of major and trace elements were measured by geochemical packages Code $4 \mathrm{~B}$ (lithium metaborate-tetraborate fusion ICP whole rock) and Code 4B2 (trace element ICP-MS), respectively.

\section{Calculation of the geochemical background}

The concentration average of each measured element was obtained considering the number of samples, and weighted taking into account the exposure area for each lithological unit from sectors A, B and C. Then, weighted average values of major and trace element for the three sectors were used to obtain the natural geochemical background of rocks from the entire Sonora river upper basin. Because of the comparatively small area covered by quartzite and regional metamorphic rocks of units 9 and 10, respectively, they were not considered in the calculation.

\section{RESULTS AND DISCUSSION}

\section{Major and trace elements}

The average concentrations of major and trace elements for samples from the lithological units of sectors A, B and C are shown in Table 2. The weighted average of elemental values of Sectors A, B and C, as well as the entire basin, are shown in Table 3 . These values are considered to represent the geochemical background of the study area, and do not have any petrogenetic significance since the lithological units are constituted by geological formations of different nature and age. Figure 3 shows that the lithological units from the three sectors have similar geochemical patterns when normalized to the Upper Continental Crust (UCC) composition proposed by Rudnick and Gao (2003), defining a relatively narrow strip close to the reference line, for most elements, particularly for the rare earth elements group (REE).

The concentrations of $\mathrm{CaO}$ and $\mathrm{P}_{2} \mathrm{O}_{5}$ are around 1.5 times the UCC abundance, which is relatively more obvious in Sector C (Figure 4). The $\mathrm{CaO}$ anomaly may be associated with limestone, intermediate and felsic volcanic rocks, as well as with altered rocks. The relatively high values of $\mathrm{P}_{2} \mathrm{O}_{5}$ may be due to the influence of volcanic rocks. In contrast, $\mathrm{Na}_{2} \mathrm{O}$ is slightly depleted, probably indicating it was partially removed in solution. Moreover, manganese is commonly removed by hydrothermal fluids and weathering processes, and further deposited in cavities, fractures and crusts, mainly as oxides, hydroxides or carbonates (Figure 3).

Regarding the trace element concentrations, the three sectors display similar patterns with relative enrichments in $\mathrm{As}, \mathrm{Ag}, \mathrm{Sb}, \mathrm{Pb}$ and $\mathrm{Bi}$ relative to the UCC (Figure 4). This enrichment is higher in Sector C, which is attributed to the influence of mineralized zones, particularly in San Felipe, Santa Elena and Baviácora (Figure 1). The enrichment of Ag, Sb and As is about 10 times the UCC; Ag and As concentration values are correlated to intermediate volcanic rocks and unconsolidated detrital deposits, whereas $\mathrm{Sb}$ is preferentially associated with felsic volcanic rocks, unconsolidated detrital deposits, and altered rocks. The other elemental positive anomalies ( $\mathrm{Ba}, \mathrm{Cu}, \mathrm{Pb}, \mathrm{Bi}$, Th and $\mathrm{U}$ ) 


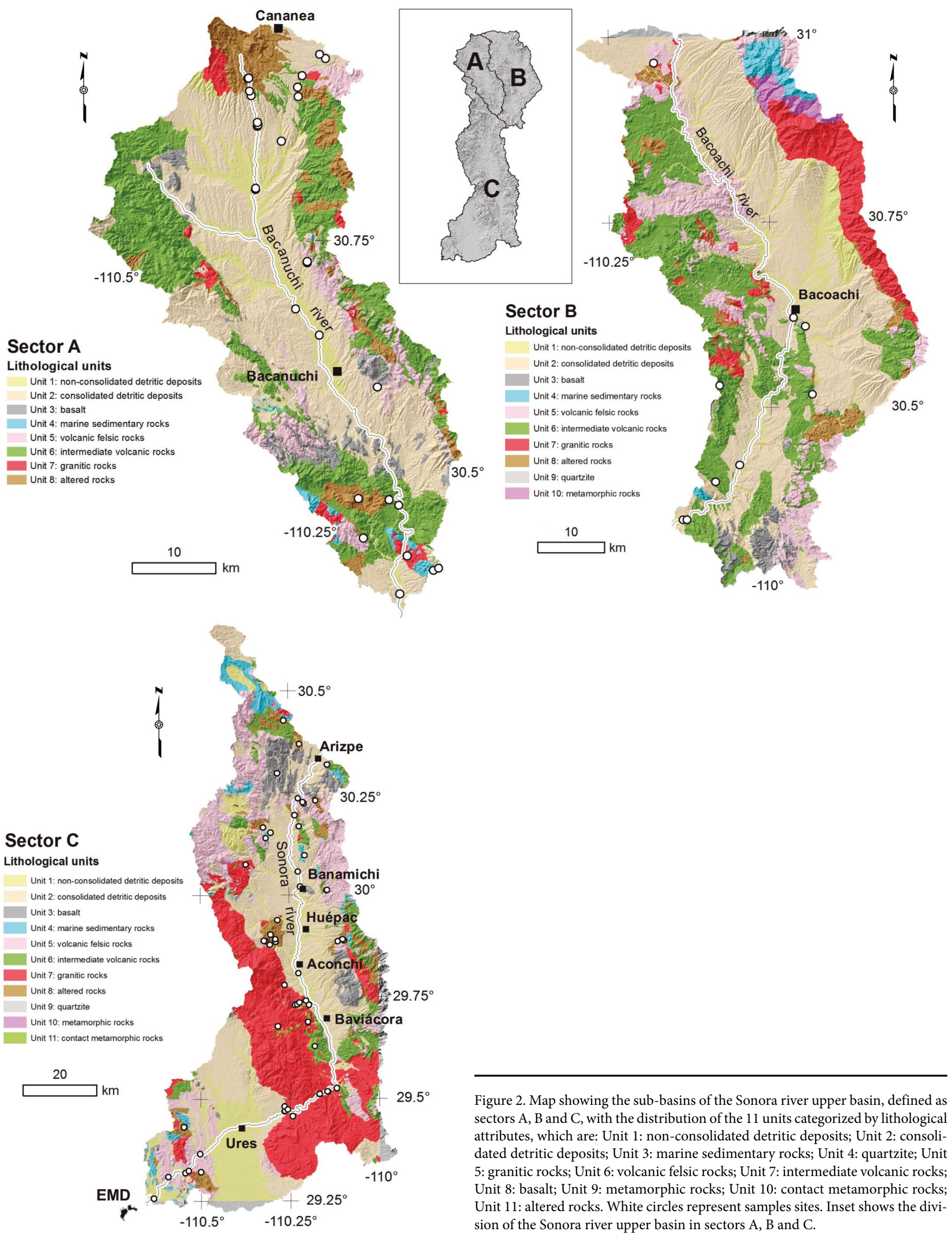


Table 2. Average concentrations of major (wt.\%) and trace (ppm) elements for each lithologic unit in sectors A, B, and C of the Sonora river upper basin.

\begin{tabular}{|c|c|c|c|c|c|c|c|c|c|c|c|c|c|c|c|c|c|c|c|}
\hline & \multicolumn{7}{|c|}{ Sector A } & \multicolumn{5}{|c|}{ Sector B } & \multicolumn{7}{|c|}{ Sector C } \\
\hline & 1 & 2 & 4 & 5 & 6 & 7 & 8 & 1 & 2 & 4 & 5 & 6 & 1 & 2 & 3 & 5 & 6 & 7 & 8 \\
\hline $\mathrm{SiO}_{2}$ & 65.4 & 61.3 & 55.6 & 71.1 & 65.2 & 66.6 & 75.0 & 65.9 & 62.7 & 95.3 & 70.7 & 55.3 & 66.2 & 70.2 & 55.5 & 72.6 & 72.3 & 72.8 & 71.2 \\
\hline $\mathrm{Al}_{2} \mathrm{O}_{3}$ & 14.9 & 15.3 & 16.4 & 15.0 & 16.1 & 16.9 & 13.7 & 14.8 & 15.4 & 2.2 & 16.4 & 11.4 & 12.0 & 15.4 & 16.8 & 14.9 & 10.7 & 14.1 & 10.9 \\
\hline $\mathrm{FeOt}$ & 4.5 & 6.6 & 6.8 & 3.5 & 4.5 & 3.2 & 2.5 & 5.1 & 5.9 & 1.0 & 2.3 & 2.0 & 7.9 & 3.6 & 8.5 & 2.4 & 4.0 & 2.6 & 3.4 \\
\hline $\mathrm{MnO}$ & 0.1 & 0.1 & 0.1 & 0.1 & 0.1 & 0.1 & 0.1 & 0.1 & 0.1 & 0.0 & 0.0 & 0.1 & 2.0 & 0.1 & 0.1 & 0.1 & 0.1 & 0.1 & 0.1 \\
\hline $\mathrm{MgO}$ & 2.0 & 2.0 & 6.6 & 0.5 & 4.1 & 1.2 & 0.7 & 2.1 & 2.8 & 0.3 & 0.7 & 0.8 & 1.0 & 0.9 & 3.6 & 1.7 & 2.0 & 0.9 & 1.3 \\
\hline $\mathrm{CaO}$ & 7.6 & 9.0 & 7.8 & 3.4 & 1.5 & 3.4 & 1.7 & 6.0 & 5.1 & 0.3 & 0.5 & 24.0 & 6.7 & 3.5 & 7.1 & 2.7 & 6.0 & 2.1 & 8.3 \\
\hline $\mathrm{Na}_{2} \mathrm{O}$ & 1.6 & 1.8 & 2.0 & 1.9 & 3.9 & 4.1 & 1.9 & 2.4 & 3.4 & 0.0 & 3.9 & 2.7 & 1.6 & 2.2 & 3.6 & 1.7 & 1.8 & 3.3 & 1.3 \\
\hline $\mathrm{K}_{2} \mathrm{O}$ & 3.0 & 2.6 & 3.5 & 3.8 & 3.7 & 3.7 & 4.1 & 2.8 & 3.5 & 0.6 & 4.7 & 3.4 & 2.1 & 3.5 & 2.5 & 3.4 & 2.5 & 3.6 & 3.2 \\
\hline $\mathrm{TiO}_{2}$ & 0.6 & 0.9 & 0.9 & 0.5 & 0.7 & 0.6 & 0.3 & 0.7 & 0.8 & 0.1 & 0.5 & 0.3 & 0.4 & 0.6 & 1.6 & 0.3 & 0.5 & 0.4 & 0.3 \\
\hline $\mathrm{P}_{2} \mathrm{O}_{5}$ & 0.2 & 0.3 & 0.3 & 0.1 & 0.2 & 0.2 & 0.1 & 0.2 & 0.3 & 0.1 & 0.0 & 0.1 & 0.1 & 0.1 & 0.7 & 0.1 & 0.1 & 0.1 & 0.1 \\
\hline $\mathrm{Sc}$ & 9.0 & 13.8 & 15.0 & 4.3 & 10.0 & 5.0 & 7.7 & 10.0 & 14.0 & 2.0 & 4.0 & 3.0 & 5.6 & 7.9 & 15.7 & 5.3 & 10.5 & 5.6 & 3.9 \\
\hline $\mathrm{Be}$ & 1.5 & 1.6 & 2.0 & 1.8 & 2.0 & 2.0 & 2.3 & 2.0 & 2.0 & 1.0 & 2.0 & 1.8 & 2.5 & 2.4 & 2.0 & 3.1 & 1.5 & 2.4 & 2.0 \\
\hline V & 77.5 & 136.6 & 121.5 & 46.3 & 96.0 & 57.0 & 39.3 & 100.0 & 118.3 & 22.0 & 37.0 & 25.0 & 51.8 & 74.3 & 159.3 & 37.5 & 86.0 & 36.6 & 30.1 \\
\hline $\mathrm{Ba}$ & 1280.0 & 888.2 & 530.5 & 991.3 & 1226.0 & 1069.0 & 374.7 & 995.0 & 1088.5 & 1901.0 & 1317.0 & 895.3 & 528.8 & 838.0 & 1047.7 & 999.7 & 549.7 & 798.5 & 700.5 \\
\hline $\mathrm{Sr}$ & 250.5 & 507.4 & 575.0 & 342.8 & 339.0 & 527.0 & 170.0 & 470.0 & 637.5 & 50.0 & 269.0 & 413.7 & 334.5 & 351.9 & 664.7 & 521.9 & 293.3 & 310.4 & 155.9 \\
\hline $\mathrm{Y}$ & 23.5 & 22.8 & 20.5 & 19.8 & 21.0 & 18.0 & 30.0 & 21.0 & 24.3 & 15.0 & 23.0 & 16.0 & 16.3 & 19.9 & 32.0 & 25.0 & 19.0 & 20.9 & 24.4 \\
\hline $\mathrm{Zr}$ & 178.0 & 188.4 & 150.5 & 127.3 & 214.0 & 216.0 & 195.7 & 179.0 & 195.8 & 99.0 & 238.0 & 163.3 & 151.5 & 164.4 & 322.0 & 160.0 & 158.3 & 168.0 & 140.9 \\
\hline $\mathrm{Cr}$ & 35.0 & 56.0 & 135.0 & 10.0 & 90.0 & 10.0 & 10.0 & 60.0 & 77.5 & 70.0 & 10.0 & 13.3 & 27.5 & 21.4 & $\quad 63.3$ & 15.7 & 53.3 & 40.0 & 30.7 \\
\hline Co & 12.5 & 13.6 & 19.5 & 7.3 & 15.0 & 7.0 & 4.7 & 12.0 & 16.8 & 1.0 & 3.0 & 2.2 & 26.3 & 5.9 & 26.7 & 4.4 & 11.2 & 5.0 & 3.3 \\
\hline $\mathrm{Ni}$ & 10.0 & 18.0 & 75.0 & 10.0 & 40.0 & 10.0 & 10.0 & 10.0 & 25.0 & 10.0 & 10.0 & 10.0 & 10.0 & 10.0 & 36.7 & 10.0 & 20.0 & 15.4 & 10.0 \\
\hline $\mathrm{Cu}$ & 45.0 & 56.0 & 30.0 & 8.8 & 40.0 & 5.0 & 23.3 & 30.0 & 30.0 & 20.0 & 5.0 & 6.7 & 237.5 & 13.6 & 30.0 & 10.7 & 5.0 & 35.0 & 49.3 \\
\hline $\mathrm{Zn}$ & 120.0 & 103.0 & 85.0 & 47.5 & 80.0 & 50.0 & 150.0 & 80.0 & 87.5 & 140.0 & 60.0 & 48.3 & 2536.5 & 68.6 & 100.0 & 69.3 & 43.3 & 74.6 & 835.7 \\
\hline $\mathrm{Ga}$ & 15.5 & 16.0 & 19.5 & 14.8 & 20.0 & 20.0 & 21.7 & 15.0 & 17.0 & 4.0 & 18.0 & 12.7 & 15.0 & 16.9 & 20.3 & 15.7 & 12.7 & 17.0 & 13.4 \\
\hline $\mathrm{Ge}$ & 1.0 & 1.1 & 1.3 & 1.4 & 1.0 & 2.0 & 1.0 & 1.0 & 1.8 & 3.0 & 2.0 & 0.8 & 1.0 & 1.7 & 1.3 & 1.6 & 1.2 & 1.9 & 1.4 \\
\hline As & 25.0 & 25.4 & 5.3 & 9.4 & 36.0 & 2.5 & 16.2 & 20.0 & 28.5 & 8.0 & 2.5 & 2.5 & 8.4 & 16.1 & 4.0 & 9.8 & 2.5 & 2.5 & 70.5 \\
\hline $\mathrm{Rb}$ & 103.5 & 88.0 & 72.0 & 130.5 & 124.0 & 132.0 & 208.3 & 91.0 & 112.0 & 39.0 & 165.0 & 99.0 & 79.8 & 145.3 & 61.0 & 122.9 & 84.7 & 167.7 & 146.5 \\
\hline $\mathrm{Nb}$ & 7.5 & 8.4 & 8.0 & 7.0 & 8.0 & 9.0 & 8.7 & 8.0 & 9.0 & 4.0 & 9.0 & 6.3 & 8.1 & 10.0 & 16.3 & 16.7 & 7.2 & 11.4 & 9.1 \\
\hline Mo & 1.0 & 1.6 & 1.0 & 1.0 & 2.0 & 1.0 & 1.3 & 1.0 & 1.0 & 7.0 & 1.0 & 1.0 & 2.8 & 1.1 & 1.0 & 1.1 & 1.0 & 1.5 & 2.7 \\
\hline $\mathrm{Ag}$ & 0.4 & 0.5 & 0.4 & 0.3 & 0.7 & 0.3 & 0.4 & 0.3 & 0.4 & 0.7 & 0.7 & 0.5 & 9.3 & 0.6 & 0.8 & 1.0 & 0.4 & 3.1 & 1.5 \\
\hline In & 0.1 & 0.1 & 0.1 & 0.1 & 0.1 & 0.1 & 0.1 & 0.1 & 0.1 & 0.1 & 0.1 & 0.1 & 0.1 & 0.1 & 0.1 & 0.3 & 0.1 & 0.1 & 1.0 \\
\hline $\mathrm{Sn}$ & 1.5 & 1.3 & 1.5 & 0.6 & 1.0 & 2.0 & 2.3 & 1.0 & 1.3 & 0.5 & 0.5 & 0.7 & 2.9 & 1.6 & 2.0 & 3.6 & 1.5 & 1.3 & 1.8 \\
\hline $\mathrm{Sb}$ & 9.4 & 7.2 & 2.4 & 12.1 & 0.9 & 0.3 & 4.7 & 4.5 & 4.3 & 4.3 & 0.3 & 0.8 & 1.7 & 5.8 & 0.3 & 3.3 & 0.8 & 0.5 & 6.9 \\
\hline Cs & 14.3 & 8.2 & 6.8 & 10.0 & 6.7 & 3.7 & 20.1 & 9.2 & 10.7 & 5.4 & 6.5 & 6.0 & 5.7 & 16.6 & 2.2 & 18.1 & 7.0 & 2.7 & 6.9 \\
\hline $\mathrm{La}$ & 30.1 & 33.4 & 27.9 & 29.1 & 39.8 & 38.2 & 38.4 & 29.3 & 31.8 & 13.5 & 41.1 & 33.3 & 26.2 & 31.3 & 52.0 & 38.6 & 19.2 & 33.8 & 29.7 \\
\hline $\mathrm{Ce}$ & 61.0 & 67.6 & 58.7 & 61.1 & 78.8 & 72.5 & 77.6 & 56.6 & 66.3 & 25.4 & 68.7 & 61.6 & 51.2 & 60.6 & 108.3 & 74.4 & 38.3 & 62.5 & 60.6 \\
\hline $\operatorname{Pr}$ & 7.0 & 7.9 & 7.1 & 6.3 & 8.8 & 7.7 & 8.7 & 6.5 & 7.5 & 3.3 & 8.2 & 6.4 & 5.8 & 6.8 & 12.5 & 7.8 & 4.5 & 6.5 & 6.3 \\
\hline $\mathrm{Nd}$ & 25.8 & 30.2 & 27.6 & 23.9 & 32.5 & 27.6 & 32.3 & 24.1 & 28.6 & 12.6 & 30.2 & 21.9 & 21.2 & 24.2 & 49.4 & 26.0 & 16.3 & 22.3 & 22.0 \\
\hline Sm & 5.3 & 5.7 & 5.3 & 4.7 & 5.7 & 5.0 & 6.1 & 4.7 & 5.7 & 2.6 & 5.0 & 3.4 & 3.8 & 4.5 & 9.5 & 4.6 & 3.3 & 3.9 & 3.9 \\
\hline $\mathrm{Eu}$ & 1.2 & 1.4 & 1.4 & 1.0 & 1.2 & 1.1 & 0.5 & 1.1 & 1.3 & 0.4 & 1.1 & 0.7 & 0.8 & 1.0 & 2.4 & 0.7 & 0.7 & 0.9 & 0.7 \\
\hline Gd & 4.2 & 4.8 & 4.7 & 3.6 & 4.5 & 3.6 & 4.9 & 3.9 & 5.0 & 2.3 & 4.3 & 2.5 & 3.1 & 3.9 & 7.8 & 4.0 & 3.3 & 3.4 & 3.4 \\
\hline $\mathrm{Tb}$ & 0.7 & 0.7 & 0.7 & 0.5 & 0.6 & 0.5 & 0.8 & 0.6 & 0.8 & 0.3 & 0.6 & 0.4 & 0.4 & 0.6 & 1.2 & 0.6 & 0.5 & 0.5 & 0.5 \\
\hline Dy & 3.9 & 4.0 & 3.8 & 3.1 & 3.3 & 2.7 & 5.0 & 3.5 & 4.2 & 2.0 & 3.5 & 1.9 & 2.6 & 3.1 & 6.4 & 3.8 & 2.9 & 3.0 & 3.3 \\
\hline Но & 0.8 & 0.8 & 0.8 & 0.6 & 0.6 & 0.5 & 1.0 & 0.7 & 0.9 & 0.4 & 0.7 & 0.4 & 0.6 & 0.6 & 1.2 & 0.8 & 0.6 & 0.6 & 0.7 \\
\hline $\mathrm{Er}$ & 2.2 & 2.3 & 2.0 & 1.8 & 2.0 & 1.3 & 3.2 & 1.9 & 2.4 & 1.2 & 2.0 & 1.1 & 1.5 & 1.8 & 3.5 & 2.3 & 1.8 & 1.8 & 2.1 \\
\hline $\mathrm{Tm}$ & 0.3 & 0.3 & 0.3 & 0.3 & 0.3 & 0.2 & 0.5 & 0.3 & 0.4 & 0.2 & 0.3 & 0.2 & 0.2 & 0.3 & 0.5 & 0.4 & 0.3 & 0.3 & 0.3 \\
\hline $\mathrm{Yb}$ & 2.2 & 2.2 & 1.9 & 1.9 & 1.8 & 1.5 & 3.3 & 2.0 & 2.5 & 1.1 & 2.1 & 1.1 & 1.7 & 1.8 & 3.1 & 2.5 & 1.8 & 1.9 & 2.3 \\
\hline $\mathrm{Lu}$ & 0.4 & 0.4 & 0.3 & 0.3 & 0.3 & 0.2 & 0.6 & 0.3 & 0.4 & 0.2 & 0.3 & 0.2 & 0.3 & 0.3 & 0.5 & 0.4 & 0.3 & 0.3 & 0.4 \\
\hline $\mathrm{Hf}$ & 4.8 & 4.9 & 4.0 & 3.6 & 6.0 & 5.7 & 5.8 & 4.9 & 5.0 & 2.6 & 5.9 & 4.0 & 3.9 & 4.2 & 7.2 & 4.8 & 4.0 & 4.5 & 3.5 \\
\hline $\mathrm{Ta}$ & 0.6 & 0.5 & 0.5 & 0.7 & 0.6 & 0.7 & 0.8 & 0.7 & 0.7 & 0.3 & 0.9 & 0.5 & 0.7 & 0.9 & 0.9 & 1.5 & 0.6 & 1.2 & 0.9 \\
\hline $\mathrm{W}$ & 3.0 & 2.9 & 0.5 & 2.8 & 3.0 & 2.0 & 1.5 & 1.0 & 3.0 & 3.0 & 2.0 & 0.7 & 31.0 & 3.6 & 1.7 & 3.0 & 16.0 & 2.0 & 79.1 \\
\hline $\mathrm{Tl}$ & 0.7 & 0.5 & 0.4 & 0.6 & 0.3 & 0.4 & 0.9 & 0.4 & 0.5 & 0.1 & 0.4 & 0.4 & 0.6 & 0.7 & 0.1 & 1.0 & 0.4 & 0.6 & 0.9 \\
\hline $\mathrm{Pb}$ & 39.5 & 29.8 & 11.5 & 11.5 & 43.0 & 11.0 & 44.0 & 21.0 & 27.5 & 139.0 & 20.0 & 16.8 & 1082.3 & 24.7 & 12.3 & 224.0 & 8.0 & 358.8 & 101.0 \\
\hline $\mathrm{Bi}$ & 0.5 & 0.3 & 0.2 & 0.2 & 0.2 & 0.2 & 0.6 & 0.2 & 0.2 & 0.2 & 0.2 & 0.2 & 16.9 & 0.5 & 0.2 & 0.3 & 0.2 & 1.2 & 0.6 \\
\hline Th & 9.3 & 11.9 & 5.6 & 13.5 & 26.5 & 14.8 & 18.7 & 10.5 & 9.6 & 3.0 & 18.3 & 9.9 & 9.7 & 12.9 & 5.1 & 18.9 & 6.2 & 16.6 & 13.6 \\
\hline U & 2.7 & 3.7 & 1.6 & 2.9 & 4.9 & 5.7 & 3.5 & 3.4 & 3.3 & 2.0 & 3.7 & 2.7 & 3.1 & 3.6 & 1.3 & 4.3 & 2.3 & 4.6 & 4.8 \\
\hline
\end{tabular}


Table 3. Weighted average of major (wt.\%) and trace (ppm) element composition of rock samples from sectors A, B, and C. SRUB stands for the natural geochemical values for the Sonora river upper basin, calculated from sectors $A$, $\mathrm{B}$ and $\mathrm{C}$, and weighted according to their areas. R\&G are the elemental values of the upper continental crust according to Rudnick and Gao (2003).

\begin{tabular}{|c|c|c|c|c|c|}
\hline & Sector A & Sector B & Sector C & SRUB & R\&G \\
\hline $\mathrm{SiO}_{2}$ & 60.39 & 58.40 & 64.51 & 62.52 & 66.6 \\
\hline $\mathrm{Al}_{2} \mathrm{O}_{3}$ & 14.25 & 13.65 & 13.62 & 13.73 & 15.4 \\
\hline $\mathrm{Fe}_{2} \mathrm{O}_{3}$ & 5.16 & 5.40 & 3.31 & 4.06 & 5.04 \\
\hline $\mathrm{MnO}$ & 0.09 & 0.11 & 0.07 & 0.08 & 0.1 \\
\hline $\mathrm{MgO}$ & 2.23 & 2.37 & 1.14 & 1.58 & 2.48 \\
\hline $\mathrm{CaO}$ & 4.65 & 5.57 & 4.54 & 4.78 & 3.59 \\
\hline $\mathrm{Na}_{2} \mathrm{O}$ & 2.32 & 2.82 & 2.60 & 2.61 & 3.27 \\
\hline $\mathrm{K}_{2} \mathrm{O}$ & 3.01 & 3.25 & 3.23 & 3.20 & 2.8 \\
\hline $\mathrm{TiO}_{2}$ & 0.67 & 0.72 & 0.47 & 0.56 & 0.64 \\
\hline $\mathrm{P}_{2} \mathrm{O}_{5}$ & 0.22 & 0.25 & 0.14 & 0.17 & 0.15 \\
\hline $\mathrm{Sc}$ & 10.80 & 11.86 & 6.85 & 8.57 & 14 \\
\hline $\mathrm{Be}$ & 1.82 & 1.97 & 2.32 & 2.16 & 2.1 \\
\hline V & 100.82 & 101.22 & 56.67 & 73.39 & 97 \\
\hline $\mathrm{Ba}$ & 971.68 & 1099.78 & 854.39 & 926.34 & 628 \\
\hline $\mathrm{Sr}$ & 397.72 & 762.11 & 400.86 & 478.61 & 320 \\
\hline $\mathrm{Y}$ & 22.78 & 22.68 & 22.07 & 22.32 & 21 \\
\hline $\mathrm{Zr}$ & 191.37 & 192.98 & 174.22 & 181.03 & 193 \\
\hline $\mathrm{Cr}$ & 55.88 & 72.50 & 29.41 & 42.98 & 92 \\
\hline Co & 12.40 & 14.70 & 6.38 & 9.15 & 17.3 \\
\hline $\mathrm{Ni}$ & 22.64 & 27.84 & 12.55 & 17.48 & 47 \\
\hline $\mathrm{Cu}$ & 42.48 & 23.12 & 12.69 & 19.72 & 28 \\
\hline $\mathrm{Zn}$ & 96.35 & 79.22 & 70.14 & 76.31 & 67 \\
\hline $\mathrm{Ga}$ & 17.63 & 16.26 & 16.29 & 16.50 & 17.5 \\
\hline $\mathrm{Ge}$ & 1.11 & 1.83 & 1.32 & 1.39 & 1.4 \\
\hline As & 25.55 & 27.90 & 12.48 & 17.91 & 4.8 \\
\hline $\mathrm{Rb}$ & 115.24 & 108.29 & 128.19 & 121.80 & 84 \\
\hline $\mathrm{Nb}$ & 8.18 & 9.06 & 11.57 & 10.48 & 12 \\
\hline Mo & 1.57 & 1.07 & 1.15 & 1.20 & 1.1 \\
\hline $\mathrm{Ag}$ & 0.51 & 0.37 & 0.62 & 0.55 & 0.053 \\
\hline In & 0.10 & 0.10 & 0.10 & 0.10 & 0.056 \\
\hline $\mathrm{Sn}$ & 1.30 & 1.06 & 1.38 & 1.30 & 2.1 \\
\hline $\mathrm{Sb}$ & 5.68 & 3.40 & 2.68 & 3.31 & 0.4 \\
\hline Cs & 9.33 & 14.47 & 9.07 & 10.28 & 3.67 \\
\hline $\mathrm{La}$ & 35.27 & 34.71 & 34.06 & 34.39 & 31 \\
\hline $\mathrm{Ce}$ & 71.00 & 69.69 & 64.87 & 66.90 & 63 \\
\hline $\operatorname{Pr}$ & 8.04 & 7.94 & 7.07 & 7.42 & 7.1 \\
\hline $\mathrm{Nd}$ & 30.09 & 30.12 & 25.17 & 27.03 & 27 \\
\hline $\mathrm{Sm}$ & 5.62 & 5.74 & 4.60 & 5.01 & 4.7 \\
\hline $\mathrm{Eu}$ & 1.21 & 1.37 & 0.98 & 1.10 & 1 \\
\hline $\mathrm{Gd}$ & 4.56 & 4.89 & 3.97 & 4.26 & 4 \\
\hline $\mathrm{Tb}$ & 0.66 & 0.70 & 0.58 & 0.62 & 0.7 \\
\hline Dy & 3.78 & 3.88 & 3.39 & 3.56 & 3.9 \\
\hline Ho & 0.72 & 0.79 & 0.68 & 0.71 & 0.83 \\
\hline Er & 2.22 & 2.18 & 1.98 & 2.06 & 2.3 \\
\hline $\mathrm{Tm}$ & 0.32 & 0.33 & 0.30 & 0.31 & 0.3 \\
\hline $\mathrm{Yb}$ & 2.15 & 2.23 & 2.04 & 2.10 & 1.96 \\
\hline $\mathrm{Lu}$ & 0.36 & 0.34 & 0.33 & 0.34 & 0.31 \\
\hline $\mathrm{Hf}$ & 5.22 & 4.84 & 4.60 & 4.75 & 5.3 \\
\hline $\mathrm{Ta}$ & 0.61 & 0.68 & 1.07 & 0.91 & 0.9 \\
\hline $\mathrm{W}$ & 2.77 & 2.53 & 3.83 & 3.38 & 1.9 \\
\hline $\mathrm{Tl}$ & 0.52 & 0.46 & 0.58 & 0.54 & 0.9 \\
\hline $\mathrm{Pb}$ & 33.76 & 23.92 & 20.13 & 23.14 & 17 \\
\hline $\mathrm{Bi}$ & 0.30 & 0.20 & 0.32 & 0.29 & 0.16 \\
\hline Th & 16.79 & 9.74 & 14.43 & 13.79 & 10.5 \\
\hline $\mathrm{U}$ & 3.90 & 3.27 & 3.91 & 3.77 & 2.7 \\
\hline
\end{tabular}

are relatively more influenced by rocks of the Báucarit Formation and unconsolidated detrital deposits of the Sonora Group and, into a lesser extent, by altered rocks. The highly positive anomaly of $\mathrm{W}$ in Sector $\mathrm{C}$ is associated with the occurrence of scheelite-rich skarn deposits located in the Aconchi batholith, southwest of Baviácora (Figure 1).

\section{Conservative reference elements}

Elements that are abundant in the Earth's crust, and their concentrations are not substantially changed by human activities and the biogeochemical cycles, are referred to as conservative or reference elements (Galuszka and Migaszewski, 2011), which include Al, Zr, Sc, Cs, Ti, Y, Ce, among others. The coefficient of variation, defined as the ratio of the standard deviation $(\sigma)$ to the mean $(\bar{x})$, is used to determine the conservative capability of an element (Reimann and de Caritat, 2005). However, some elements, traditionally considered as conservative, may display a similar or higher variability than certain elements considered as pollutants in environmental studies (Reimann and Garrett, 2005).

Commonly, the determination of environmental indexes (e.g. enrichment factor, geo-accumulation index, pollution index, concentration factor) is based on comparing the concentration of an element with a globally accepted reference, for instance, the continental crust (Monsalve et al., 2017; Saleem et al., 2018; Hasan et al., 2018). However, to obtain more realistic reference values, the using of elemental concentrations of either local or regional geochemical values is preferred by many authors (e.g. Kř́bek et al., 2014; Wu et al., 2014; Zhang et al., 2014; Christou et al., 2017; Pan et al., 2017a; Pan et al., 2017b; Shang et al., 2017; Akopyan et al., 2018). Therefore, for the calculation of environmental indexes, particularly the enrichment factor, it is essential the using of conservative reference elements.

In the case of rocks of the Sonora river upper basin, the geochemical background shows a great variability in some elements due to the lithological diversity and the presence of locally altered and mineralized zones. According to the calculated coefficient of variation values (Figure 5), eight conservative reference elements were identified on the basis of their low coefficient of variation values ( $\mathrm{Sc}, \mathrm{Y}, \mathrm{Zr}, \mathrm{Ce}, \mathrm{Yb}$, $\mathrm{Fe}, \mathrm{Ti}$ and $\mathrm{Al}$ ). Therefore, these elements are recommended to assess contamination in environmental media (sediments, soils, surficial or underground water, etc.) to perform further studies in the Sonora river upper basin.

Regarding the elements commonly considered as potentially toxic, only $\mathrm{As}, \mathrm{Sb}, \mathrm{Pb}, \mathrm{W}, \mathrm{Bi}, \mathrm{Zn}$ and $\mathrm{Cu}$ exhibit positive elemental anomalies in the geochemical background with respect to the UCC (Figure 4). Moreover, these elements are also characterized by having higher coefficient of variation values, as pointed out for soil samples from two large-scale geochemical studies in northern Europe (Reimann and de Caritat, 2005).

\section{Implications for mining activities in Mexico}

In Mexico, there is a lack of environmental regulations to establish a geochemical background prior to the development, or during the operation of a mine. As far as we know, this is the first large-scale study in Mexico that was carried out with the purpose of defining the geochemical background in a region, where mineralized areas are widespread, and mining industry is a priority activity. The establishment of the geochemical background should be considered as a basic tool to avoid misinterpretations of abnormally high elemental values, particularly those considered as potentially toxic, which can be wrongly attributed to mining activity instead of natural concentrations. For the case of the Sonora river upper basin, the geochemical background serves as a reference for the studied media in the region (e.g. soil, dust, sediments). 

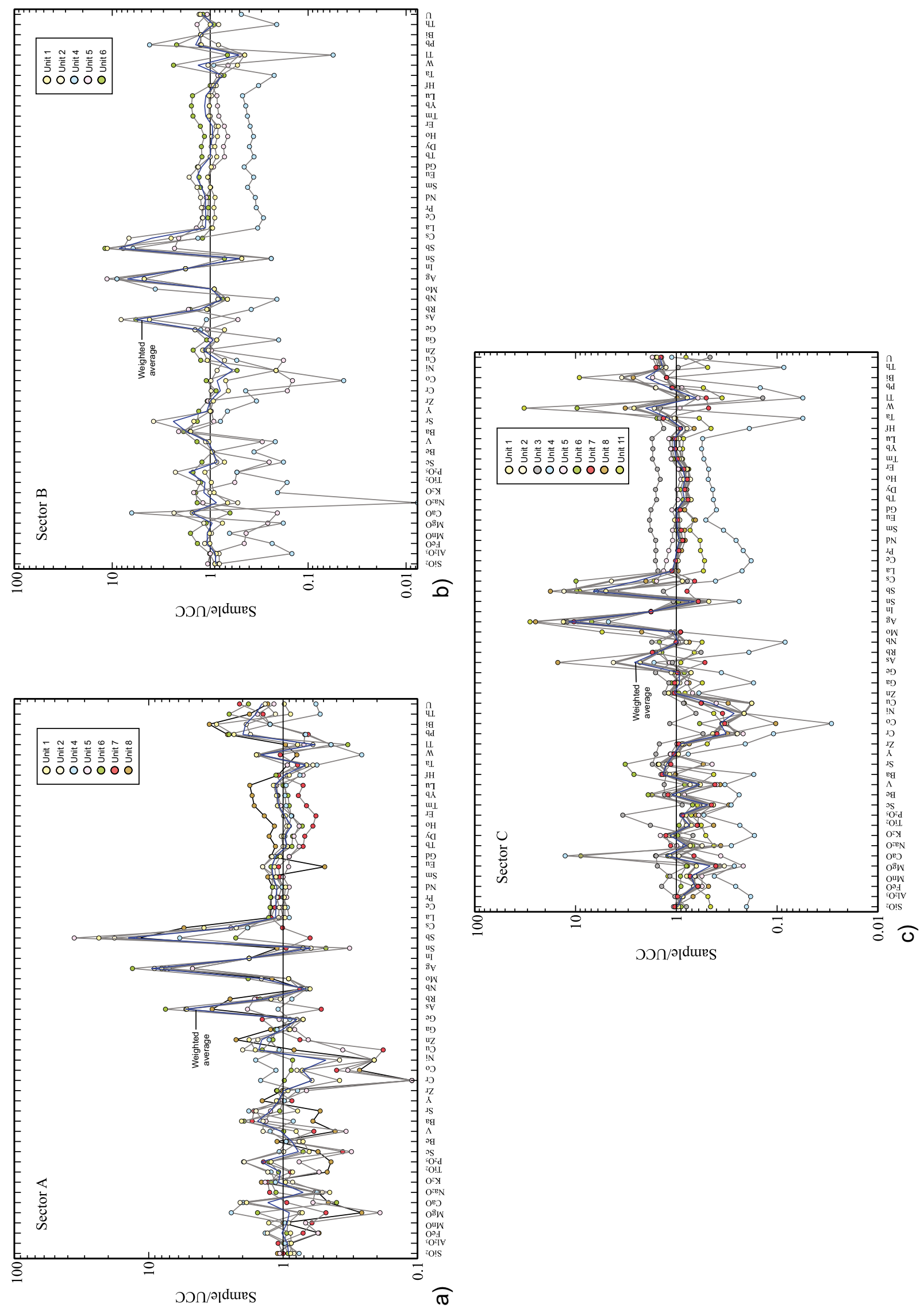

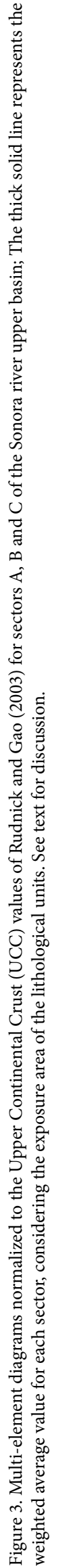


Figure 4. Multi-element diagram normalized to the Upper Continental Crust (UCC) of Rudnick and Gao (2003) showing the weighted average values for sectors $\mathrm{A}$ (dotted line), $\mathrm{B}$ (dashed line), C (thin solid line) and for the entire basin (blue solid line).

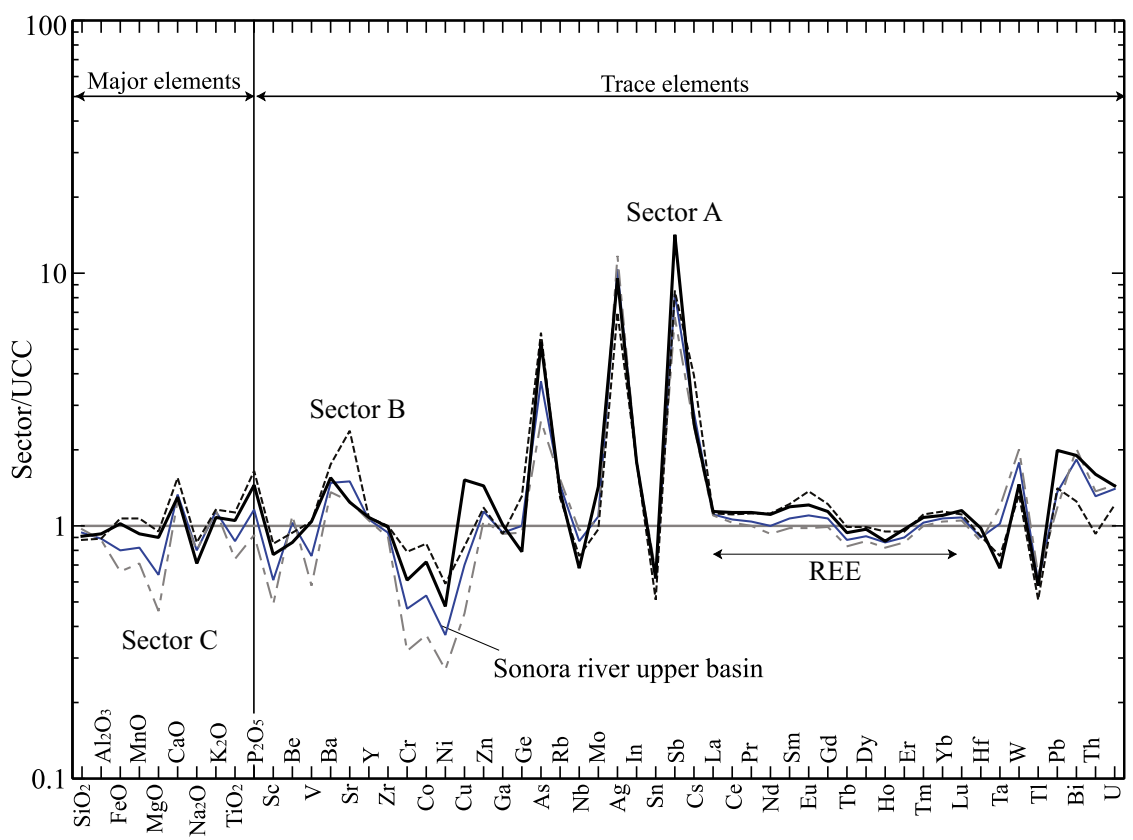

\section{CONCLUSIONS}

A geological survey was conducted in the Sonora river upper basin to establish its geochemical background. The basin was divided into three sectors, which represent the main three sub-basins. The rocks of the three sectors display similar geochemical patterns when normalized to the upper continental crust (Rudnick and Gao, 2003). These patterns define a narrow strip close to the reference line for the REE and relatively little variations for major elements. However, the data show that rocks from the three sectors exhibit naturally derived positive anomalies in some elements, particularly in $\mathrm{Mn}, \mathrm{Ca}, \mathrm{P}, \mathrm{Ba}, \mathrm{Zn}, \mathrm{As}, \mathrm{Ag}$, $\mathrm{Sb}, \mathrm{W}, \mathrm{Pb}$ and $\mathrm{Bi}$. Considering that soils and sediments are derived from surrounding rocks by weathering processes and pedogenesis, they may inherit the geochemical signature, which can be wrongly attributed

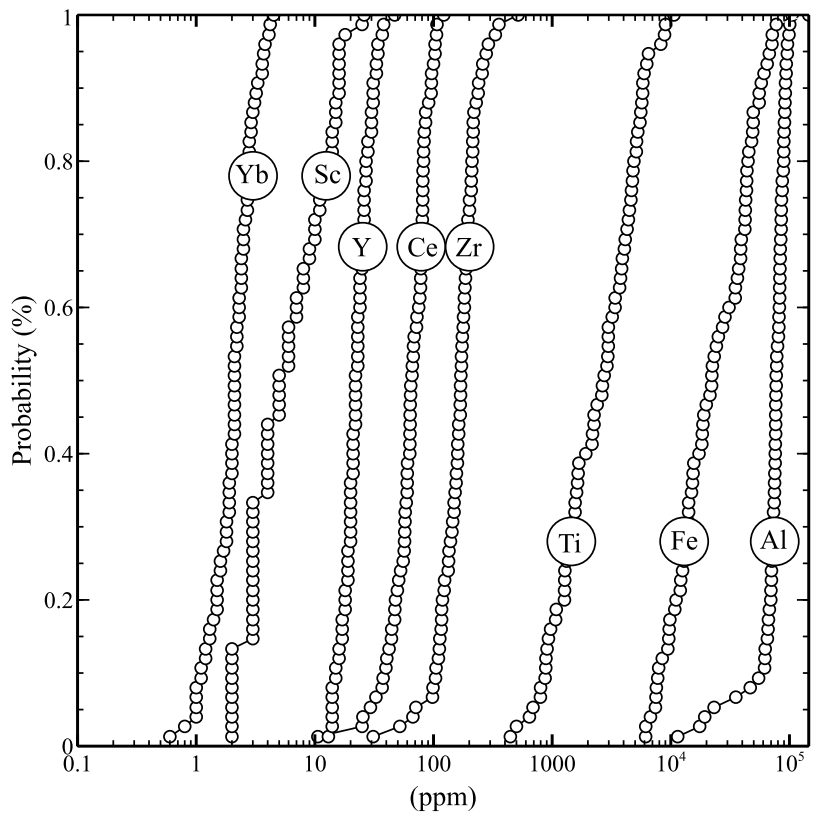

to anthropogenic activities. Statistical data based on the coefficient of variation indicate that $\mathrm{Sc}, \mathrm{Y}, \mathrm{Zr}, \mathrm{Ce}, \mathrm{Yb}, \mathrm{Fe}, \mathrm{Ti}$ and $\mathrm{Al}$ can be considered as conservative reference elements, suggesting them as good candidates to determine environmental indexes in environmental studies in the upper Río Sonora basin.

As a summary of this study, the local geochemical background is preferred to the average values of the upper continental crust in environmental studies, because it takes into account the geological and lithological characteristics of the area. As a matter of fact, and considering that this is an important mining region at national scale, the obtained geochemical background sheds light regarding the natural concentration of some potentially toxic elements if released into the environment by natural and anthropogenic processes, that can be misinterpreted in environmental studies.

\section{ACKNOWLEDGEMENTS}

This work was financially supported by a SEMARNAT-UNAM agreement through the Fideicomiso río Sonora (Sonora river trust). We are thankful to J.J. García and G. Juárez for logistic and field assistance, and to P. Peñaflor-Escárcega for rock sample preparation. We thank John S. Armstrong-Altrin and an anonymous reviewer for the valuable comments that improved the manuscript.

\section{REFERENCES}

Akopyan, K., Petrosyan, V., Grigoryan, R., Melkomian, D.M., 2018, Assessment of residential soil contamination with arsenic and lead in mining and smelting towns of northern Armenia: Journal of Geochemical Exploration, 184, 97-109.

Figure 5. Probability diagram showing the most conservative reference elements for the Sonora river upper basin. Aluminum and yttrium yield the lowest coefficient of variation. 
Anderson, T.H., Silver, L.T., 1977, U-Pb isotope ages of granitic plutons near Cananea, Sonora: Economic Geology, 72, 827-836.

Anderson, T.H., Silver, L.T., 2005, The Mojave-Sonora megashear-field and analytical studies leading to the conception and evolution of the hypothesis, in Anderson, T.H., Nourse, J.A., McKee, J.W., Steiner, M.B. (eds.), The Mojave-Sonora megashear hypothesis-development, assessment, and alternatives. Geological Society of America Special Paper 393, 1-50.

Chiprés, J.A., Salinas, J.C., Castro-Larragoitia, J., Monroy, M.G., 2008, Geochemical mapping of major and trace elements in soils from the Altiplano Potosino, Mexico: A multi-scale comparison: Geochemistry: Exploration, Environment, Analysis, 8, 279-290.

Chiprés, J.A., Castro-Larragoitia, J., Monroy, M.G., 2009, Exploratory and spatial data analysis (EDA-SDA) for determining regional background levels and anomalies of potentially toxic elements in soils from Catorce-Matehuala, Mexico: Applied Geochemistry, 24, 1579-1589.

Christou, A., Theologides, C.P., Costa, C., Kalavrouziotis, I.K. Varnavas, S.P., 2017, Assessment of toxic heavy metals concentrations in soils and wild and cultivated plant species in Limni abandoned copper mining site, Cyprus: Journal of Geochemical Exploration, 178, 16-22.

Coney, P.J., Reynolds, S.J., 1977, Cordilleran Benioff zones: Nature, 270, 403-406.

Dickinson, W.R., Lawton, T.F., 2001, Carboniferous to Cretaceous fragmentation and assembly of Mexico: Geological Society of America Bulletin, 113, 1142-1160.

Gałuszka, A., Migaszewski, Z., 2011, Geochemical background-environmental perspective: Mineralogia, 42, 7-17.

González-León, C.M., Valencia, V., López. M., Bellon, H., Valencia-Moreno, M., Calmus, T., 2010, Arizpe sub-basin: A sedimentary and volcanic record of Basin and Range extensión in north-central Sonora, Mexico: Revista Mexicana de Ciencias Geológicas, 27, 292-312.

Grijalva-Noriega, F.J., Roldán-Quintana, J., 1998, An overview of the Cenozoic tectonic and magmatic evolution of Sonora, northwestern Mexico: Revista Mexicana de Ciencias Geológicas, 15, 145-156.

Gutierrez, M., Reyes-Gómez, V.M., Alarcón-Herrera, M.T., Núñez-Lopez, D., 2012, Exploratory analysis of sediment geochemistry to determine the source and dispersion of $\mathrm{Ba}, \mathrm{Fe}, \mathrm{Mn}, \mathrm{Pb}$ and $\mathrm{Cu}$ and in Chihuahua, Northern Mexico: Journal of Geography and Geology, 4, 26-39.

Hao, L., Zhao, X., Zhao, Y., Lu, J., Sun, L., 2014, Determination of the geochemical background and anomalies in areas with variable lithologies: Journal of Geochemical Exploration, 139, 177-182.

Hasan, M., Kausar, D., Akhter, G., Shah, M.H., 2018, Evaluation of the mobility and pollution index of selected essential/toxic metals in paddy soil by sequential extraction method: Ecotoxicology and Environmental Safety, 147, 283-291.

Hawkes, H.E., Webb, J.S., 1962, Geochemistry in mineral exploration: Geochimica et Cosmochimica Acta, 27, 715-716.

Iriondo, A., Premo, W.R., 2011, Las rocas cristalinas proterozoicas de Sonora y su importancia para la reconstrucción del margen continental SW de Laurencia - La pieza mexicana del rompecabezas de Rodinia, in Calmus, T. (ed.), Panorama de la geología de Sonora, México: Universidad Nacional Autónoma de México, Instituto de Geología, Boletín 118, 25-55.

Kř́bek, B., Majer, V., Pašava, J., Kamona, F., Mapani, B., Keder, J. Ettler, V., 2014, Contamination of soils with dust fallout from the tailings dam at the Rosh Pinah area, Namibia: Regional assessment, dust dispersion modeling and environmental consequences: Journal of Geochemical Exploration, 144, 391-408.

Martínez, J., Llamas, J., de Miguel, E., Rey, J., Hidalgo, M.C., 2007, Determination of the geochemical background in a metal mining site: example of the mining district of Linares (South Spain): Journal of Geochemical Exploration, 94, 19-29.

Mauel, D.J., Lawton, T.F., González-León, C.M., Iriondo, A., Amato, J.M., 2011, Stratigraphy and age of Upper Jurassic strata in north-central Sonora, Mexico: Southwestern Laurentian record of crustal extension and tectonic transition: Geosphere, 7, 390-414.

Miranda-Avilés, R., Puy-Alquiza, M.J. and Pérez Arvizu, O., 2012, Anthropogenic metal content and natural background of overbank sediments from the mining district of Guanajuato, Mexico: Soil and Sediment Contamination: An International Journal, 21, 604-624.

Monsalve, S.M., Martínez, L., Vásquez, K.Y., Orellana, S.A., Vergara, J.K., Mateo, M.M., Salazar, R.C., Alburquenque, M.F., Lillo, D.D.C., 2017,
Trace element contents in fine particulate matter (PM2.5) in urban school microenvironments near a contaminated beach with mine tailings, Chañaral, Chile: Environmental Geochemistry and Health, 1-15.

Noguez-Alcántara, B., 2008, Reconstrucción del modelo genético y evolución tectónica del yacimiento tipo pórfido cuprífero Milpillas, Distrito de Cananea, Sonora, Mexico: Hermosillo, Sonora, Mexico, Posgrado en Ciencias de la Tierra, Universidad Nacional Autónoma de México, PhD Thesis, $390 \mathrm{pp}$.

Nordstrom, D.K., 2015, Baseline and premining geochemical characterization of mined sites: Applied Geochemistry, 57, 17-34.

Page, W.R., Gray, F., Iriondo, A., Miggins, D., Blodgett, R.B., Maldonado, F., Miller, R.J., 2010, Stratigraphy and Mesozoic-Cenozoic tectonic history of northern Sierra Los Ajos and adjacent areas, Sonora, Mexico: Journal of South American Earth Sciences, 29, 557-571.

Pan, H., Lu, X., Lei, K., 2017a, Lead in roadway dusts from different functional areas in a typical valley city, NW China: contamination and exposure risk: Environmental Science and Pollution Research, doi.org/10.1007/ s11356-017-0467-3.

Pan, L., Wang, Y., Ma, J., Hu, Y., Su, B., Fang, G., Wang, L., Xiang, B., 2017b, A review of heavy metal pollution levels and health risk assessment of urban soils in Chinese cities: Environmental Science and Pollution Research, doi. org/10.1007/s11356-017-0513-1.

Reimann, C., Garrett, R.G., 2005, Geochemical background - concept and reality: Science of the Total Environment, 350, 12-27.

Reimann, C., de Caritat, P., 2005, Distinguishing between natural and anthropogenic sources for elements in the environment: regional geochemical surveys versus enrichment factors: Science of the Total Environment, 337, 91-107.

Roldán-Quintana, J., 1991, Geology and chemical composition of El Jaralito and Aconchi batholiths in east-central Sonora, in Pérez-Segura, E. Jacques-Ayala, C. (eds.), Studies of Sonoran Geology: Geological Society of America Special Paper 254, 19-36.

Rudnick, R.L., Gao, S., 2003, Composition of the continental crust: Treatise on Geochemistry, Elsevier, 3, 1-64.

Saleem, M., Iqbal, J., Akhter, G., Shah, M.H., 2018, Fractionation, bioavailability, contamination and environmental risk of heavy metals in the sediments from a freshwater reservoir, Pakistan: Journal of Geochemical Exploration $184,199-208$

Salminen, R., Gregorauskiene, G., 2000, Considerations regarding the definition of a geochemical baseline of elements in the superficial materials in areas differing in the geology: Applied Geochemistry, 15, 647-653.

Shang, S., Zhong, W., Wei, Z., Zhu, C., Ye, S., Tang, X., Chen, Y., Tian, L. and Chen, B., 2017, Heavy metals in surface sediments of lakes in Guangzhou public parks in China and their relations with anthropogenic activities and urbanization: Human and Ecological Risk Assessment: An International Journal, 23(8), 2002-2016.

Stewart, J.H., Poole, F.G., 2002, Inventory of Neoproterozoic and Paleozoic strata in Sonora, Mexico: U.S. Geological Survey, Open File Report 02-97, 50 pp.

Titley, S.R., 1993, Characteristics of porphyry copper occurrence in the American Southwest, in Kirkham, R.V., Sinclair, W.D., Thorpe, R.I., Duke, J.M. (eds.), Mineral deposit modeling. Geological Association of Canada Special Paper 40, 433-464.

Valenzuela-Navarro, L.C., Valencia-Moreno, M., Calmus, T., Ochoa-Landín, L., González-León, C., 2005, Marco geológico-estructural del pórfido de molibdeno El Crestón, Sonora Central, México: Revista Mexicana de Ciencias Geológicas, 22(3), 345-357.

Wu, J., Teng, Y., Lu, S., Wang, Y., Jiao, X., 2014, Evaluation of soil contamination indices in a mining area of Jiangxi, China: PloS one, 9(11), e112917. https:// doi.org/10.1371/journal.pone.0112917.

Zhang, H., Chen, J., Zhu, L., Yang, G. Li, D., 2014, Anthropogenic mercury enrichment factors and contributions in soils of Guangdong Province, South China: Journal of Geochemical Exploration, 144, 312-319.

Manuscript received: december 11, 2017

Corrected manuscript received: march 7, 2018

Manuscript accepted: april 4, 2018 